\title{
Comparison of water depth tolerance in two major wetland macrophytes, Phragmites australis and Typha angustifolia
}

\author{
U. SONG \\ Department of Biology, Jeju National University, 690-756 Jeju, South Korea
}

\begin{abstract}
Two major emergent macrophytes, Phragmites australis and Typha angustifolia, show a clear zonation with respect to water depth, i.e., P. australis occupies shallower water than T. angustifolia. However, the reasons for this interspecific difference is unclear. Therefore, this study focused on the features that enable T. angustifolia to survive at greater water depths than $P$. australis. In both outdoor and greenhouse experiments, $P$. australis did not survive at the deepest water depth and showed significantly lower biomass, nitrogen content, and photosynthesis in most deep and/or aerated water than T. angustifolia. Differences in tolerances to changes in the water depth and responses to root aeration may underlie the clear zonation of the two species. As $T$. angustifolia and $P$. australis are both very common in wetlands around the world, understanding the causal factors determining their depth distributions, such as differences in photosynthetic rate at different depths, will be of great importance for managing or controlling these species.
\end{abstract}

Keywords: antioxidant enzyme activity; cattail; ecophysiology; photosynthesis; reed; wetland.

\section{Introduction}

Wetlands are important ecosystems for biodiversity conservation, nutrient retention, and water supply (Tiner 1984), and provide many ecosystem services of benefit to humans (Carlsson et al. 2003). Wetlands are also believed to play an important role in mitigating future global climate change (Erwin 2009, Song et al. 2013). Wetland macrophytes have several intrinsic properties that make them important ecosystem components. Macrophytes stabilize the sediment surface and provide a habitat for attached microbial growth (Brix 1994). Their remediation ability helps improve water quality (Song et al. 2018), and they provide shelter for many other species (Gregg and Rose 1982).

Reeds (Phragmites spp.) and cattails (Typha spp.) are representative emergent macrophytes in freshwater (Maddison et al. 2009, Rejmankova 2011). They show a clear zonation with respect to water depth, with the common reed, Phragmites australis (Cav.) Trin. ex Steud., occupying shallower and slower-flowing water than the narrow-leaf cattail, Typha angustifolia L. (Asaeda et al. 2005). Song et al. (2018) found that T. angustifolia occurred at a much greater maximum water depth than $P$. australis. However, the reasons behind these interspecific differences are not clear. Differences in germination under submerged conditions (Coops and van der Velde 1995), oxygen demand/aeration (Yamasaki 1984), niche competition (Findlay et al. 2002), morphological plasticity (Bellavance and Brisson 2010), ability to elongate shoots rapidly above the water surface (de Assis Murillo et al. 2019), formation of adventitious roots (Pedersen et al. 2017), and molecular signaling pathways involved in germination under submergence (Pedersen et al. 2017) may allow $T$. angustifolia to outcompete $P$. australis in deep water conditions. Also, the fundamental niche of

\section{Highlights}

- Reed and cattail show a clear zonation with respect to water depth

- Cattail showed higher resilience of photosynthesis to water depth and better use of root aeration

- Causal factors determining reed and cattail depth distributions were discovered
Received 27 February 2020

Accepted 9 March 2021

Published online 6 April 2021

e-mail: uhrami@gmail.com

Abbreviations: $\mathrm{Chl}$ - chlorophyll; TAA - total antioxidant activity.

Acknowledgements: This research is supported by National Research Foundation of Korea (2019R1I1A2A03061067).

Conflict of interest: The author declares no conflict of interest. 
$P$. australis for water depth would be much lower than that of T. angustifolia. However, while important features of submerged plants, such as photosynthesis (Spence and Chrystal 1970), antioxidant enzyme activity (Li et al. 2011), and nutrient availability (Yuan et al. 2016), have been studied, there is little information on emergent macrophytes, in particular, there have been no studies relating plant features to a water depth. Consequently, this study of zonation in P. australis and T. angustifolia focuses on the features that enable cattails to survive at greater water depths. It was tested whether the difference in (1) photosynthetic rate change by water depth and (2) ability to utilize dissolved oxygen could be a factor affecting survival water depth of two species (T. angustifolia has bigger maximum water depth than $P$. australis).

\section{Materials and methods}

Plant depth limits in the study area: The study area, Sudokwon landfill in Incheon, South Korea (37 $34^{\prime} 52^{\prime \prime N}$, $\left.126^{\circ} 37^{\prime} 29^{\prime \prime} \mathrm{E}\right)$, has one of the world's largest leachate processing facilities (Song et al. 2018). The landfill has buffering wetlands, which were constructed during landfill construction to minimize the environmental impact of the emitted leachate. However, these 15-years (at the time of study) old wetlands did not consider ecological features of remediation plant during construction that only edge of the wetlands is covered with macrophytes at the time of this research (Song et al. 2018). Three vegetated buffer wetlands (termed A, B, and C) were used as study sites. The maximum depth limits of $P$. australis and T. angustifolia were measured in June 2007.

Outdoor tank experiment: In April 2007, rhizome clusters (400 g) of P. australis and T. angustifolia harvested from buffering wetlands were planted in pots (diameter of $36 \mathrm{~cm}$, height of $45 \mathrm{~cm}$ ) with sand and placed in a tank $(2 \times 5 \times 1.2 \mathrm{~m})$ with running water at depths of 10,40 , or $70 \mathrm{~cm}$ (10 replicates per treatment). The experiment was designed to reenact the situation where the shoot from the rhizome penetrates the water layer to rise to the surface of the water in spring. The $70-\mathrm{cm}$ maximum experimental depth was set to exceed the observed natural depth limit for P. australis $(\sim 60 \mathrm{~cm})$. There was also a negative depth treatment with water level approximately $5 \mathrm{~cm}$ below the sand surface. Ten replicates were used for each treatment and species combination. The mass per unit area of rhizomes in each pot was set at the value recorded in wetland A (400 g $\left.0.1 \mathrm{~m}^{-2}\right)$. Pot depths were modified by standing them on blocks. Nutrients were supplied to each pot in the form of $15 \mathrm{~g}$ Osmocote (Osmocote Plus $[13 \% \mathrm{~N}+13 \% \mathrm{P}+13 \% \mathrm{~K}+2 \% \mathrm{MgO}]$, Scotts International B.V., Geldermalsen, Netherlands). The photosynthetic rates and chlorophyll (Chl) content of the experimental plants were measured in August. Plants were harvested for biomass and nutrient measurement in late October. )

Greenhouse experiment: The greenhouse experiment used both plants grown from rhizomes and from seeds. In the first category, $35 \mathrm{~g}$ of rhizomes were planted in each pot (diameter of $108 \mathrm{~mm}$, height of $120 \mathrm{~mm}$, six replicates per treatment) with the same mass per unit area as the tank experiment. For seed-grown treatments, plants were transferred to pots $45 \mathrm{~d}$ after germination. To test the physiological responses of plants to water depth and level of aeration, plants were grown at three experimental depths: negative $(-5 \mathrm{~cm})$, shallow $(5 \mathrm{~cm})$, and deep $(35 \mathrm{~cm})$. Treatments involved either aeration (air flow of $7 \mathrm{~L} \mathrm{~min}^{-1} \mathrm{~m}^{-2}$ ) at the bottom of the pots or no aeration to determine whether root aerobic respiration capacity affects growth (Matsui and Tsuchiya 2006). Plants were grown in coarse sand and perlite to maximize air flow to the roots. Photosynthetic rates and total antioxidant activity (TAA) were measured in July 2010, one month after planting. Dissolved oxygen (DO) was measured using a portable DO meter (YSI Model 30, YSI, Yellow Springs, USA). Plants were harvested for biomass and nutrient measurement after the 3-month growing period.

Analytical methods: Photosynthesis of aerial leaves was measured at $30^{\circ} \mathrm{C}$ and $400 \mathrm{ppm} \mathrm{CO}_{2}$ using a portable photosynthesis measurement system ( $\mathrm{Li}$-6400, LI-COR Biosciences, Lincoln, USA). Leaf chlorophyll (Chl) content was measured by extraction with dimethyl sulfoxide (Hiscox and Israelstam 1979) using a spectophotometer (SpectraMax, Molecular Devices, San Jose, USA). Carbon and nitrogen contents were measured with an elemental analyzer (Flash EA 1112; Thermo Electron, San Jose, USA).

For antioxidant enzyme activities, plant leaves $(0.1 \mathrm{~g})$ were frozen in liquid nitrogen, and $50 \mathrm{mM}$ phosphate buffer ( $\mathrm{pH}$ 7.2) was used for extraction. TAA was measured by determining antioxidant activity of organic liquid using bathocuproine (Song and Lee 2010). TAA values were determined by examining induced changes of spectrophotometric measurements (SpectraMax, Molecular Devices, San Jose, USA) at $490 \mathrm{~nm}$ by copper sulfate solution addition. Plant leaves for analysis were collected from the second highest branch from the top.

Statistical analysis: Differences between two treatments (or species) were analyzed using the Mann-Whitney's $U$ test. One-way analysis of variance (ANOVA) was used to test differences between treatments. When a significant difference $(P<0.05)$ was detected, a post hoc Duncan's multiple range test was performed using the ANOVA procedure in SAS 9.1 (SAS Institute, Cary, USA). Correlation matrix results among biotic parameters were analyzed using $R$ 3.1.2 (open-source software, $R$ Developmental Core Team).

\section{Results}

Plant depth limits in the study area: The two species showed a clear difference in maximum recorded depth of occurrence in the landfill study area (Table 1). T. angustifolia was found at greater depths in all three wetlands of the landfill. There was a clear zonation between the two species in the wetlands; $T$. angustifolia inhabited deeper areas than that of $P$. australis. 
Outdoor tank experiment for comparison of maximum depth tolerance: The $\mathrm{Chl}$ content of $T$. angustifolia increased with the water depth. By contrast, $P$. australis did not survive at $70-\mathrm{cm}$ depth and showed a significant decrease in the $\mathrm{Chl}$ content as the depth increased from -5 to 10 and $40 \mathrm{~cm}$ (Table 2). For $P$. australis, the rate of photosynthesis was significantly lower in the $40-\mathrm{cm}$ depth treatment than that in the negative depth treatment $(-5 \mathrm{~cm}$, Fig. 1A). T. angustifolia showed the opposite pattern (Fig. 1A), consistent with the differences in Chl content.

The biomass of $P$. australis declined significantly with the water depth (Fig. $2 A$ ), with $100 \%$ mortality in the $70-\mathrm{cm}$ depth treatment. The aboveground biomass in the $40-\mathrm{cm}$ water depth was only $\sim 20 \%$ of that in the negative depth treatment $(-5 \mathrm{~cm})$. The rhizome biomass did not increase over the course of the experiment. The aboveground biomass of $T$. angustifolia also decreased with the water depth, but values at 40 and $70-\mathrm{cm}$ depth were still 85 and $72 \%$ of the negative depth biomass, respectively (Fig. 2A). The nitrogen content decreased significantly with the water depth in both species (Fig. 2A).

\section{Greenhouse experiment for testing species response to} water depth and aeration: The biomass of T. angustifolia increased significantly with aeration, especially in the deep treatment (Fig. 2B). Seed-grown T. angustifolia survived in a deep water only when aerated. P. australis grown from rhizomes also showed a positive effect of aeration but no differences were found in seed-grown plants (Fig. 2B). The nitrogen content of $T$. angustifolia was significantly higher in aerated treatments (Fig. 3) but there were no differences in TAA (Fig. 3). Results indicate that the plants

Table 1. Maximum water depths recorded for Typha angustifolia and Phragmites australis in three Korean wetlands. Values represent means $\pm \mathrm{SE}(n=30) . P$ value - Mann-Whitney's $U$ test.

\begin{tabular}{llll}
\hline & \multicolumn{3}{c}{ Maximum water depth [cm] } \\
& Wetland A & Wetland B & Wetland C \\
\hline Typha angustifolia & $73.3 \pm 6.0$ & $94.6 \pm 7.5$ & $79.6 \pm 6.1$ \\
Phragmites australis & $56.7 \pm 3.9$ & $58.4 \pm 5.4$ & $49.5 \pm 6.3$ \\
$P$ value & $<0.001$ & $<0.001$ & $<0.001$ \\
\hline
\end{tabular}

were under severe stress in deep water and that stress (one of the factors believed to define the maximum depth at which a plant can survive) was not reduced by aeration. Aeration significantly increased the rate of photosynthesis in T. angustifolia but not in $P$. australis (Fig. $1 B, C$ ). In both species, photosynthesis declined with the increasing water depth. Correlation matrix results among biotic parameters showed a clear positive relationship among photosynthetic rate, biomass, and $\mathrm{N}$ contents while TAA results showed the negative relationship (Table 3 ).

\section{Discussion}

All three wetlands studied showed a clear zonation of $P$. australis and $T$. angustifolia, with the latter species consistently extending to much greater water depths (Table 1). This pattern is consistent with published results (Squires and van der Valk 1992, Asaeda et al. 2005). The mean depth of occurrence for $P$. australis has been reported as $\sim 45 \mathrm{~cm}$ in some areas (Coops et al. 1996), whereas the stand biomass of Typha species has been found to decrease only at depths below $85 \mathrm{~cm}$ (Waters and Shay 1992). In wetland areas of land reclamation sites (similar to the present study sites), P. australis occurs only at depths of $\sim 30 \mathrm{~cm}$ whereas $T$. angustifolia extends down to $1 \mathrm{~m}$ (Kang and Joo 1999). The results consistently showed $T$. angustifolia dominated the deeper areas and $P$. australis dominated the shallower areas of wetlands. This zonation pattern could be a reflection of niche differentiation. However, it could also be interpreted as an intermediate stage of succession, where the lower-marsh species T. angustifolia (Squires and van der Valk 1992) will eventually be replaced by the upper-marsh species $P$. australis. Wetland $\mathrm{C}$ has low values of plant water depth because leachate emission causes water depth to fluctuate over a wide range (Song 2010).

In the outdoor tank experiment, $P$. australis showed a pattern consistent with the field data by failing to survive at a depth of $70 \mathrm{~cm}$. Chl content also decreased significantly with the water depth (Table 2). By contrast, the Chl content of $T$. angustifolia was significantly higher at depths of $40 \mathrm{~cm}$ and $70 \mathrm{~cm}$, and it was the lowest at a depth of $10 \mathrm{~cm}$. The results indicate that $T$. angustifolia is well-adapted to deep water, while $P$. australis prefers

Table 2. Chlorophyll content of Typha angustifolia and Phragmites australis at different water depths (outdoor tank experiment). Values represent means $\pm \mathrm{SE}(n=5)$. Means within a column followed by the same superscript letter are not significantly different at $P=0.05$.

\begin{tabular}{lllll}
\hline Species & Water depth $[\mathrm{cm}]$ & $\mathrm{Chl} a\left[\mathrm{mg} \mathrm{L}^{-1}\right]$ & $\mathrm{Chl} b\left[\mathrm{mg} \mathrm{L}^{-1}\right]$ & Total Chl $\left[\mathrm{mg} \mathrm{L}^{-1}\right]$ \\
\hline Typha & -5 & $11.2 \pm 0.6^{\mathrm{ab}}$ & $5.2 \pm 0.3^{\mathrm{ab}}$ & $16.4 \pm 0.9^{\mathrm{ab}}$ \\
angustifolia & 10 & $7.7 \pm 1.7^{\mathrm{b}}$ & $3.6 \pm 0.8^{\mathrm{b}}$ & $11.4 \pm 2.5^{\mathrm{b}}$ \\
& 40 & $13.2 \pm 1.7^{\mathrm{a}}$ & $5.7 \pm 0.7^{\mathrm{ab}}$ & $18.9 \pm 2.4^{\mathrm{a}}$ \\
& 70 & $13.4 \pm 1.6^{\mathrm{a}}$ & $5.9 \pm 0.7^{\mathrm{a}}$ & $19.3 \pm 2.3^{\mathrm{a}}$ \\
Phragmites & -5 & $13.6 \pm 1.7^{\mathrm{b}}$ & $5.9 \pm 0.6^{\mathrm{b}}$ & $19.4 \pm 2.3^{\mathrm{b}}$ \\
australis & 10 & $17.0 \pm 0.7^{\mathrm{a}}$ & $7.3 \pm 0.2^{\mathrm{a}}$ & $24.3 \pm 0.8^{\mathrm{a}}$ \\
& 40 & $8.2 \pm 0.5^{\mathrm{c}}$ & $4.3 \pm 0.2^{\mathrm{c}}$ & $12.5 \pm 0.7^{\mathrm{c}}$ \\
& 70 & Dead & Dead & Dead \\
\hline
\end{tabular}




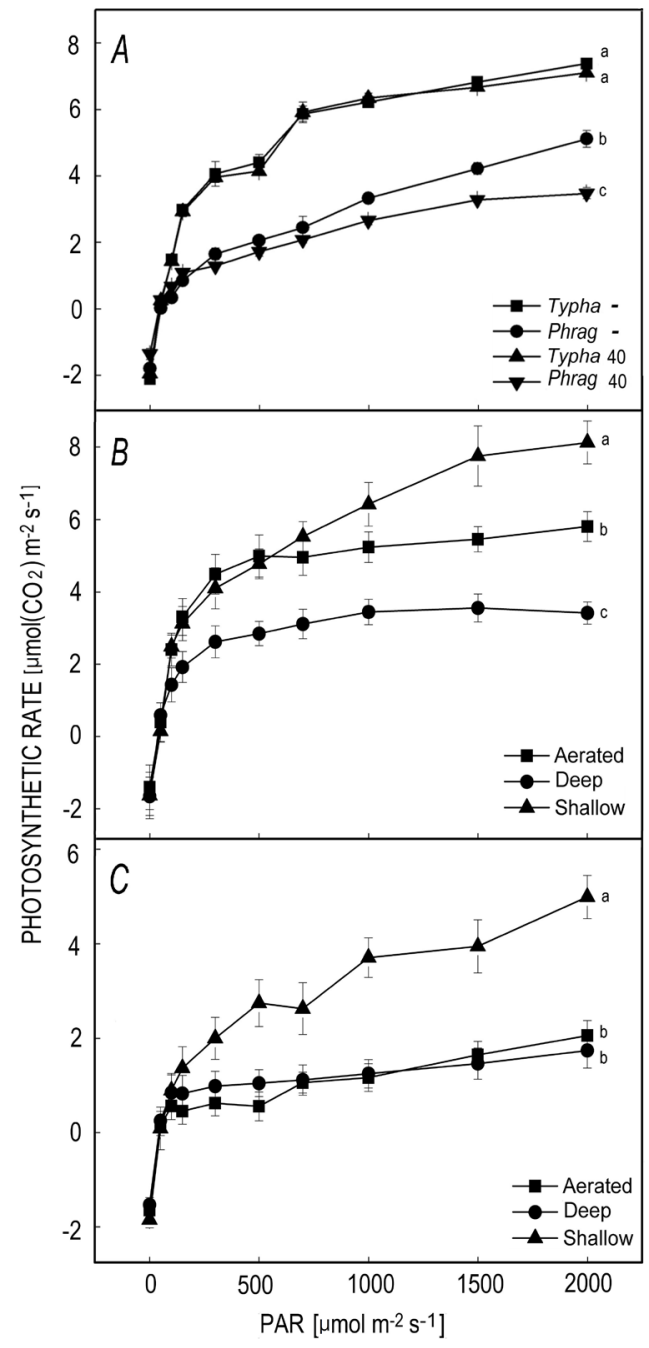

Fig. 1. Photosynthetic performance of (A) Typha angustifolia (Typha) and Phragmites australis (Phrag) (outdoor tank experiment); (B) Typha angustifolia and (C) Phragmites australis at different water depths and aeration (greenhouse experiment). Values represent mean \pm SE of four replicates. Values having the same letter are not significantly different at $P=0.05$. '-' and 40 in $(A)$ mean negative $(-)$ and $40 \mathrm{~cm}$ water depth.

shallow water. This pattern is also reflected in rates of photosynthesis (Fig. 1A), which in T. angustifolia were not affected by water depth, whereas $P$. australis showed lower rates in deeper water. The physiological activities of $T$. angustifolia appeared to be unaffected by the water depth (down to $40 \mathrm{~cm}$ ) but those of $P$. australis showed a consistent depth-related decrease. T. angustifolia showed a higher photosynthetic performance in both 10 and $40-\mathrm{cm}$ water depths. The physiological activities of $P$. australis showed a depth inhibition, while in $T$. angustifolia, the rates were unaffected down to $40 \mathrm{~cm}$, at which point performance was still higher than that in the negative $(-5 \mathrm{~cm})$ depth treatment.

The aboveground biomass of $P$. australis in $40-\mathrm{cm}$ water depth was less than $21 \%$ of the value recorded in
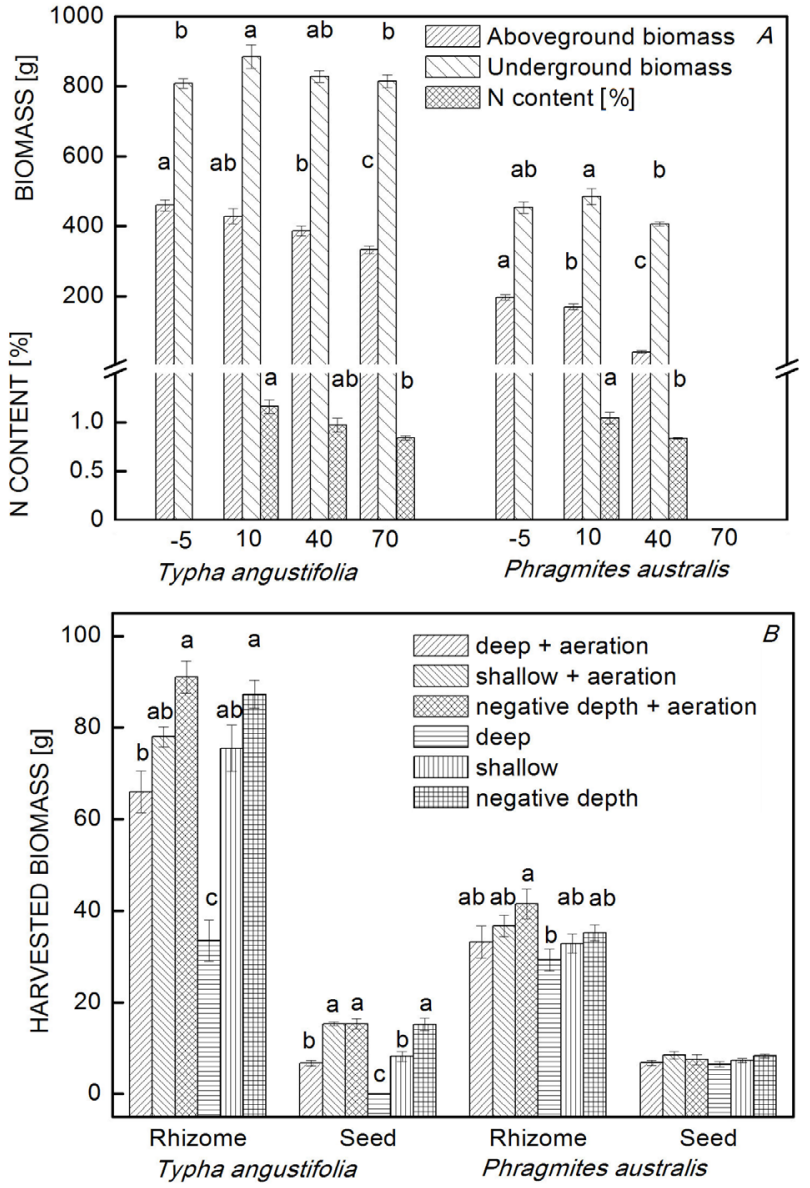

Fig. 2. (A) Harvested biomass (fresh mass) and nitrogen contents of plants (outdoor tank experiment) by water depth [cm] and (B) harvested biomass (dry mass) of plants (greenhouse experiment) by treatments. Values represent mean $\pm \mathrm{SE}$ of ten replicates $(A)$ or six replicates $(B)$. N contents of $-5-\mathrm{cm}$ water depth were not measured $(A)$. Values with the same superscript letter are not significantly different at $P=0.05$.

the negative depth treatment. T. angustifolia biomass also decreased with the water depth but the rate of decline was much lower than that in P. australis. T. angustifolia in 70-cm water still showed $72 \%$ of the aboveground biomass seen in the negative depth treatment, indicating that the species is able to grow in deep water. The underground biomass of T. angustifolia more than doubled over the course of the experiment and showed little difference between treatments. By contrast, $P$. australis showed a maximum $20 \%$ biomass increase at a depth of $10 \mathrm{~cm}$, no increase at $40 \mathrm{~cm}$, and $100 \%$ mortality at $70 \mathrm{~cm}$, indicating that the plant did not grow well in deep water. Previous studies have found that water depth does not suppress growth of Typha species (Tulbure et al. 2007) while water depth is the major factor that affects growth of $P$. australis (Engloner 2009). Plant nitrogen content decreased significantly with the water depth in both species (Fig. 2A). This indicates that although the plants may be adapted to tolerate deep water ( $T$. angustifolia), they may still experience stress (Song 2017). 
Ecophysiological parameters, such as Chl content, photosynthesis, and biomass, show clearly that T. angustifolia grows better in deep water than P. australis and is better suited to a range of static water depths (White et al. 2007). These differences explain the clear zonation of $P$. australis and T. angustifolia observed in the field.

The greenhouse experiment was designed to test the responses of plants in more tightly controlled conditions and also to test whether root aerobic respiration capacity affects plant growth (Matsui and Tsuchiya 2006). With aeration, the biomass of $T$. angustifolia increased significantly, particularly in the deep treatment (Fig. 2B). Seed-grown $T$. angustifolia survived in deep water only

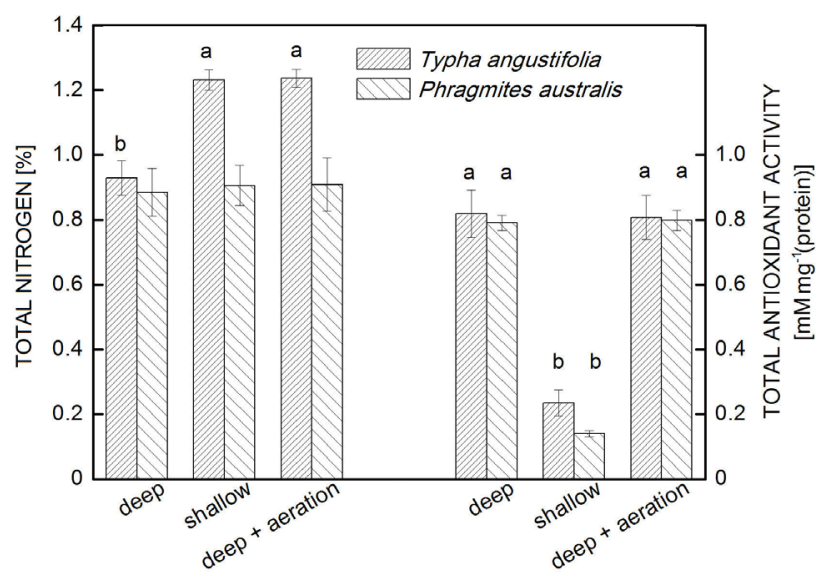

Fig. 3. Nitrogen contents and total antioxidant activity by water depth. Values represent means $\pm \operatorname{SE}(n=3)$. Values followed by the same superscript letter are not significantly different at $P=0.05$. when aerated. $P$. australis grown from rhizomes also showed a positive aeration effect but there was no difference in plants grown from seeds (Fig. 2B). Wetlands with high concentrations of dissolved oxygen, or where conditions permit root aeration (Matsui and Tsuchiya 2006) may allow T. angustifolia to grow better in deep water than $P$. australis. For $P$. australis, aeration did not significantly affect performance in the shallow treatments. In treatments without aeration, there were no differences between water depths. The lack of an aeration effect suggests that $P$. australis has a very limited ability to use dissolved oxygen. The ability to take advantage of aerobic conditions in the rooting environment may allow T. angustifolia to have a higher water depth tolerance than $P$. australis, which lacks this ability.

$P$. australis performed better than T. angustifolia in the greenhouse experiment for both rhizome- and seed-grown plants. This unexpected result may provide insight into a question why $P$. australis is the most dominant species in the study area (Incheon, Korea) and in many other countries. Results suggest that when grown from seeds, $P$. australis is more adaptable than Typha species. It appears to be a generalist able to inhabit wetlands across a wide geographic range (Ailstock et al. 2001, NHDES 2018).

Total root biomass and fine root biomass are both important factors to consider when testing the effects of root aeration. In this experiment, fine roots were all attached to perlite and were difficult to isolate from the sands. Root biomass values are therefore not presented. Dissolved oxygen (DO) was measured during the experiment and showed $\mathrm{a} \sim 50 \%$ difference between aerated and control treatments. However, the later discovery of a fault with the DO meter meant that the values recorded were unreliable,

Table 3. Correlation matrix results among biotic parameters. of Typha angustifolia and Phragmites australis. TAA - total antioxidant activity.

\begin{tabular}{|c|c|c|c|c|}
\hline \multicolumn{5}{|c|}{ Typha angustifolia correlation } \\
\hline & Photosynthetic rate & Biomass & $\mathrm{N}$ content & TAA \\
\hline Photosynthetic rate & 1.000 & 0.855 & 0.803 & -0.790 \\
\hline Biomass & 0.855 & 1.000 & 0.830 & -0.711 \\
\hline $\mathrm{N}$ content & 0.803 & 0.830 & 1.000 & -0.443 \\
\hline TAA & -0.790 & -0.711 & -0.443 & 1.000 \\
\hline \multicolumn{5}{|c|}{ Phragmites australis correlation } \\
\hline & Photosynthetic rate & Biomass & $\mathrm{N}$ content & TAA \\
\hline Photosynthetic rate & 1.000 & 0.657 & 0.086 & -0.870 \\
\hline Biomass & 0.657 & 1.000 & -0.196 & -0.748 \\
\hline $\mathrm{N}$ content & 0.086 & -0.196 & 1.000 & -0.052 \\
\hline TAA & -0.870 & -0.748 & -0.051 & 1.000 \\
\hline \multicolumn{5}{|c|}{ Correlation using both Typha angustifolia and Phragmites australis } \\
\hline & Photosynthetic rate & Biomass & $\mathrm{N}$ content & TAA \\
\hline Photosynthetic rate & 1.000 & 0.882 & 0.771 & -0.555 \\
\hline Biomass & 0.882 & 1.000 & 0.806 & -0.406 \\
\hline $\mathrm{N}$ content & 0.771 & 0.806 & 1.000 & -0.155 \\
\hline TAA & -0.555 & -0.406 & -0.155 & 1.000 \\
\hline
\end{tabular}


and they were not presented here.

Aeration significantly increased the nitrogen content of T. angustifolia (Fig. 3) but had no effect on P. australis. The $\mathrm{N}$ content of plants is an indicator of plant health (Song and Lee 2010) that shows higher values when plants are in good conditions. TAA values are also a good indicator of plant stress; when plants are under stress, the values would rise (Song and Lee 2010). TAA showed no significant aeration effects (Fig. 3). Results indicate that the plants in deep water experienced severe stress, and that this stress was not reduced by aeration. Aeration significantly increased photosynthesis in $T$. angustifolia but not in $P$. australis (Fig. 1B,C). Rates of photosynthesis in both species declined with the increasing water depth, but the extent to which this decrease can be mitigated by other factors determine their respective water depth limits. Correlation matrix shows a clear positive relationship among photosynthetic rate, biomass, and $\mathrm{N}$ contents, while TAA results shows negative relationship to other parameters (Table 3). As increased TAA indicates elevated stress of plants (Sairam et al. 2000), the results mean that photosynthetic rate, biomass, $\mathrm{N}$ contents, and less stressed conditions are positively related. Also $P$. australis shows negative correlation between $\mathrm{N}$ content and biomass as $\mathrm{N}$ contents of $P$. australis did not change by treatment while biomass significantly decreased by water depth but was not affected by aeration.

In both outdoor and indoor experiments, T. angustifolia and $P$. australis showed decreased performance with respect to biomass, nitrogen content, photosynthesis, and TAA with increasing water depth. P. australis did not survive in the deepest treatment $(70 \mathrm{~cm})$ and showed lower resilience of biomass, nitrogen content, and photosynthesis in most deep and/or aerated treatments compared to T. angustifolia. Differential tolerances to changes in water depth and responses to root aeration may underlie the clear zonation of the two species. As T. angustifolia and $P$. australis are both very common in wetlands around the world, understanding the causal factors determining their depth distributions will be of great importance for managing or controlling these species.

\section{References}

Ailstock M.S., Norman C.M, Bushmann P.J.: Common reed Phragmites australis: Control and effects upon biodiversity in freshwater nontidal wetlands. - Restor. Ecol. 9: 49-59, 2001.

Asaeda T., Fujino T., Manatunge J.: Morphological adaptations of emergent plants to water flow: a case study with Typha angustifolia, Zizania latifolia and Phragmites australis. Freshw. Biol. 50: 1991-2001, 2005.

Bellavance M.-E., Brisson J.: Spatial dynamics and morphological plasticity of common reed (Phragmites australis) and cattails (Typha sp.) in freshwater marshes and roadside ditches. Aquat. Bot. 93: 129-134, 2010.

Brix H.: Functions of macrophytes in constructed wetlands. Water Sci. Technol. 29: 71-78, 1994.

Carlsson F., Frykblom P., Liljenstolpe C.: Valuing wetland attributes: an application of choice experiments. - Ecol. Econ. 47: 95-103, 2003.

Coops H., van den Brink F.W.B., van der Velde G.: Growth and morphological responses of four helophyte species in an experimental water-depth gradient. - Aquat. Bot. 54: 11-24, 1996.

Coops H., van der Velde G.: Seed dispersal, germination and seedling growth of six helophyte species in relation to waterlevel zonation. - Freshw. Biol. 34: 13-20, 1995.

de Assis Murillo R., Corrêa Alves D., dos Santos Machado R. et al.: Responses of two macrophytes of the genus Polygonum to water level fluctuations and interspecific competition. Aquat. Bot. 157: 10-16, 2019.

Engloner A.I.: Structure, growth dynamics and biomass of reed (Phragmites australis) - A review. - Flora 204: 331-346, 2009.

Erwin K.L.: Wetlands and global climate change: the role of wetland restoration in a changing world. - Wetl. Ecol. Manag. 17: 71, 2009.

Findlay S.E.G., Dye S., Kuehn K.A.: Microbial growth and nitrogen retention in litter of Phragmites australis compared to Typha angustifolia. - Wetlands 22: 616-625, 2002.

Gregg W.W., Rose F.L.: The effects of aquatic macrophytes on the stream microenvironment. - Aquat. Bot. 14: 309-324, 1982.

Hiscox J.D., Israelstam G.F.: A method for the extraction of chlorophyll from leaf tissue without maceration. - Can. J. Bot. 57: 1332-1334, 1979.

Kang H., Joo Y.: The structural characteristics in natural wetlands and fitted depth zones of Phragmites japonica. - J. Korean Inst. Landsc. Archit. 17: 191-200, 1999.

Li F., Xie Y., Chen X. et al.: Plant distribution can be reflected by physiological responses to salinity of three submerged macrophytes from the Modern Yellow River Delta. - Fundam. Appl. Limnol. 179: 159-167, 2011.

Maddison M., Soosaar K., Mauring T., Mander Ü.: The biomass and nutrient and heavy metal content of cattails and reeds in wastewater treatment wetlands for the production of construction material in Estonia. - Desalination 246: 120-128, 2009.

Matsui T., Tsuchiya T.: Root aerobic respiration and growth characteristics of three Typha species in response to hypoxia. Ecol. Res. 21: 470-475, 2006.

NHDES (New Hampshire Department of Environmental Services): Common Reed Becoming a Common Nuisance. Pp. 2. Environmental Fact Sheet of NHDES, Concord 2018.

Pedersen O., Perata P., Voesenek L.A.C.J.: Flooding and low oxygen responses in plants. - Funct. Plant Biol. 44: iii-vi, 2017.

Rejmankova E.: The role of macrophytes in wetland ecosystems. J. Ecol. Environ. 34: 333-345, 2011.

Sairam R.K., Srivastava G.C., Saxena D.C.: Increased antioxidant activity under elevated temperatures: a mechanism of heat stress tolerance in wheat genotypes. - Biol. Plantarum 43: 245-251, 2000.

Song U.: Ecological Monitoring and Management of Plant, Soil and Leachate Channel in the Sudokwon Landfill, Korea. Ph.D Thesis. Seoul National University, Korea 2010.

Song U.: Temperature-dependent performance of competitive native and alien invasive plant species. - Acta Oecol. 84: 8-14, 2017.

Song U., Kim E., Bang J.H. et al.: Wetlands are an effective green roof system. - Build. Environ. 66: 141-147, 2013.

Song U., Lee E.J.: Ecophysiological responses of plants after sewage sludge compost applications. - J. Plant Biol. 53: 259$267,2010$.

Song U., Waldman B., Park J.S. et al.: Improving the remediation capacity of a landfill leachate channel by selecting suitable macrophytes. - J. Hydro-Environ. Res. 20: 31-37, 2018.

Spence D.H.N., Chrystal J.: Photosynthesis and zonation of 
freshwater macrophytes: II. Adaptability of species of deep and shallow water. - New Phytol. 69: 217-227, 1970.

Squires L., van der Valk A.G.: Water-depth tolerances of the dominant emergent macrophytes of the Delta Marsh, Manitoba. - Can. J. Bot. 70: 1860-1867, 1992.

Tiner R.W.: Wetlands of the United States: Current Status and Recent Trends. Pp. 59. National Wetlands Inventory, Fish and Wildlife Service, US Department of the Interior, 1984.

Tulbure M.G., Johnston C.A., Auger D.L.: Rapid invasion of a Great Lakes coastal wetland by non-native Phragmites australis and Typha. - J. Great Lakes Res. 33: 269-279, 2007.

Waters I., Shay J.M.: Effect of water depth on population parameters of a Typha glauca stand. - Can. J. Bot. 70: 349$351,1992$.

White S.D., Deegan B.M., Ganf G.G.: The influence of water level fluctuations on the potential for convective flow in the emergent macrophytes Typha domingensis and Phragmites australis. - Aquat. Bot. 86: 369-376, 2007.

Yamasaki S.: Role of plant aeration in zonation of Zizania latifolia and Phragmites australis. - Aquat. Bot. 18: 287-297, 1984.

Yuan G., Fu H., Zhong J. et al.: Growth and C/N metabolism of three submersed macrophytes in response to water depths. Environ. Exp. Bot. 122: 94-99, 2016.

(C) The authors. This is an open access article distributed under the terms of the Creative Commons BY-NC-ND Licence. 